\title{
Bank Efficiency And Financial Ratios: Rating The Performance Of The Four Largest South African Banks
}

Gerhardus van der Westhuizen, North-West University, South Africa

\begin{abstract}
Data Envelopment Analysis (DEA) in conjunction with financial ratios is used to estimate and compare the performance of the four largest South African banks over the period 2001 to 2011. DEA is used to estimate the relative technical, allocative, cost and scale efficiencies and compare these estimates to certain financial ratios published by the banks in their financial statements. These ratios include return on equity (ROE), return on assets (ROA), net interest margin (NIM), impairment losses, etc. The results obtained from the efficiency estimates and the financial ratios are used to rate the banks according to these performances. The rating differs depending on which performance measure is applied. A combination of these measures was necessary to determine the best and the worst performing bank. From the results obtained it appears that profitability and efficiency are two sides of the same coin.
\end{abstract}

Keywords: Bank Performance; Technical Efficiency; Allocative Efficiency; Scale Efficiency; Financial Ratios; Net Interest Margin; Noninterest Income

\section{INTRODUCTION}

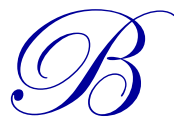

ank managers usually quote some financial ratio like return on equity (ROE) or return on assets (ROA) when they are asked to comment on the performance of their bank. According to Rose and Hudgins (2005:145) the word perform (performance) in the case of banks refers to how adequately a bank meets the objectives identified by the stockholders (owners), employees, depositors and other creditors, and borrowing customers. While managing these objectives, the bank must at the same time also meet the requirements (regulations) set by the Department of Bank Supervision at the Reserve Bank, indicating that banks operate in a regulatory environment. The first step in analysing any bank's financial statements is to decide what objectives the bank is persuing, and therefore must bank performance be directed toward specific objectives (Rose \& Hudgins, 2005).

These financial ratios (also referred to as key profitability ratios) include ratios like the rate of return on equity (ROE), rate of return on assets (ROA), net interest margin, net noninterest margin, net operating margin, and earnings per share of stock. A number of these ratios are referred to as efficiency ratios, e.g., ROA as an indicator of managerial efficiency, while net operating margin, net interest margin and net noninterest margin are efficiency as well as profitability measures (Rose \& Hudgins, 2005). For a more detailed analysis of performance, asset utilisation (AU) and the equity multiplier (EM) can be calculated. ROE is linked to ROA by the EM, and it affects a bank's profit because it has a multiplier impact on ROA to determine a bank's ROE (MacDonald \& Koch, 2006, p. 71). AU is a measure of asset management efficiency where ROE $=$ net profit margin $x$ AU $x$ EM (Rose \& Hudgins, 2005).

Risk taking is a normal behaviour of financial institutions, given that risk and expected return are so tightly interrelated (Bessis, 2002) and therefore there are various financial ratios that are peculiar to the banking industry. Banks, as managers of various risks, direct these financial ratios toward the management of that particular risk. Some of the risks facing banks are, inter alia, credit risk, liquidity risk, market risk, interest rate risk, earnings risk 
and capital risk. Each of these forms of risk can threaten a bank's solvency and long-run survival (Rose \& Hudgins, 2005). Each of these risks have specific financial ratios to evaluate that specific risk, e.g., for credit risk the ratio of nonperforming assets to total loans and leases, for liquidity risk the ratio of purchased funds to total assets, and for interest rate risk the ratio of interest-sensitive assets to interest-sensitive liabilities. Other forms of risk in banking include inflation risk, currency or exchange rate risk, political risk and crime risk (Rose \& Hudgins, 2005).

The use of financial ratios as performance measures is faced by a number of obstacles. Financial ratios are only meaningful when compared to a benchmark, and finding a suitable benchmark (e.g. the exact ROE that must be obtained before a bank is regarded as performing well) may be difficult (Yeh, 1996). Another obstacle is the fact that each performance measure is partial in the sense that it is calculated using only a subset of the data available on the firm. The problem with partial measures is that a bank may perform well using one measure (e.g. ratio of bad debts to assets) but badly using another (e.g. total costs per employee). According to Sherman and Gold (1985) financial ratios are not appropriate because they aggregate many aspects of performance such as financing, marketing and operations. A bank may appear to be performing well, even if it is poorly managed on some of these dimensions, so long as it compensates by performing particularly well on other dimensions. What is needed is a single measure of total performance that is calculated using all the input and output data available on the firm.

The abovementioned obstacles can be overcome by measurement tools that can compensate for the obstacles encountered by the use of financial ratios. Data Envelopment Analysis (DEA) and Stochastic Frontier Analysis (SFA) are some of the tools that are used for estimating efficiency (performance). (SFA) involves specifying the functional form of the frontier and then estimating its unknown parameters using econometric techniques. (DEA) effectively estimates the frontier by finding a set of linear segments that bound (or envelop) the observed data. Various studies have previously used DEA to study the performance of banks at both the firm/corporate level (e.g. Drake, 2001; Seiford \& Zhu, 1999; Devaney \& Weber, 2000; Berger \& Humphrey, 1997; Halkos \& Salamouris, 2004; Mendes \& Rebello, 1999; Luo, 2003; Resti, 1997; van der Westhuizen, 2008; van der Westhuizen \& Oberholzer, 2009; Matthews \& Zhang, 2010; Chang et al., 2012), and at the branch level (e.g. Sherman \& Ladino, 1995; Sherman \& Gold, 1985; Vassiloglou \& Giokas, 1990; Oral \& Yolalan, 1990; O'Donnell \& van der Westhuizen, 2002; van der Westhuizen \& Oberholzer, 2003; Oberholzer \& van der Westhuizen, 2004; van der Westhuizen, 2012).

This paper attempts to answer the following question: In analysing bank performance with the aid of financial ratios and DEA, and attempting to rank banks according to their performance, will the ranking order differ depending on whether DEA results or financial ratio results are used? In order to answer this question, the performance of the four largest South African banks was compared over an eleven year period. (DEA) was used to estimate the technical efficiency, allocative efficiency, cost efficiency and scale efficiency of these banks, and then various financial ratios were recorded for each of these banks. According to the average efficiency estimates and the financial ratios, the banks were ranked. The South African financial sector is dominated by four large banks, namely ABSA, FirstRand Bank, NEDBANK, and Standard Bank. According to the BA 900 reports (Department of Bank Supervision, 2009) these four banks control over 84\% of total deposits and assets in South Africa.

The remainder of the paper is divided into the following sections. Section 2 describes the DEA approach for measuring efficiency. Certain financial ratios that can be used in evaluating bank performance are discussed in Section 3. In Section 4 the data and the model for the efficiency estimates are discussed. The results from the DEA estimation as well as the results from the financial ratios are discussed in Section 5. The paper is concluded in Section 6.

The contributions of this paper are two-fold: 1) It is the first to apply DEA and financial ratios to study the performance of the four largest South African banks over an eleven year period and 2) the first to determine how the rating of the banks differ depending on whether efficiency estimates or financial ratios are applied in rating the banks. 


\section{DATA ENVELOPMENT ANALYSIS}

(DEA) can be used to estimate four main types of efficiency, namely technical, allocative, cost and scale efficiency. In practice the measurement of these efficiencies involves estimation of production frontiers. DEA effectively estimates the frontier by finding a set of linear segments that bound (or envelop) the observed data.

For example, assume the observed data comprises two-input single-output Firms M, R and A. The DEA estimate of the production frontier will be the piecewise linear surface (convex hull) VMRV' depicted in Figure. 1.

A firm is said to be technically efficient if it produces a given set of outputs using the smallest possible amount of inputs. Allocative efficiency reflects the ability of a firm to use the inputs in optimal proportions, given their respective prices. A firm is cost efficient if it is both technically and allocatively efficient. The firm is said to be scale efficient if it operates on a scale that maximises productivity.

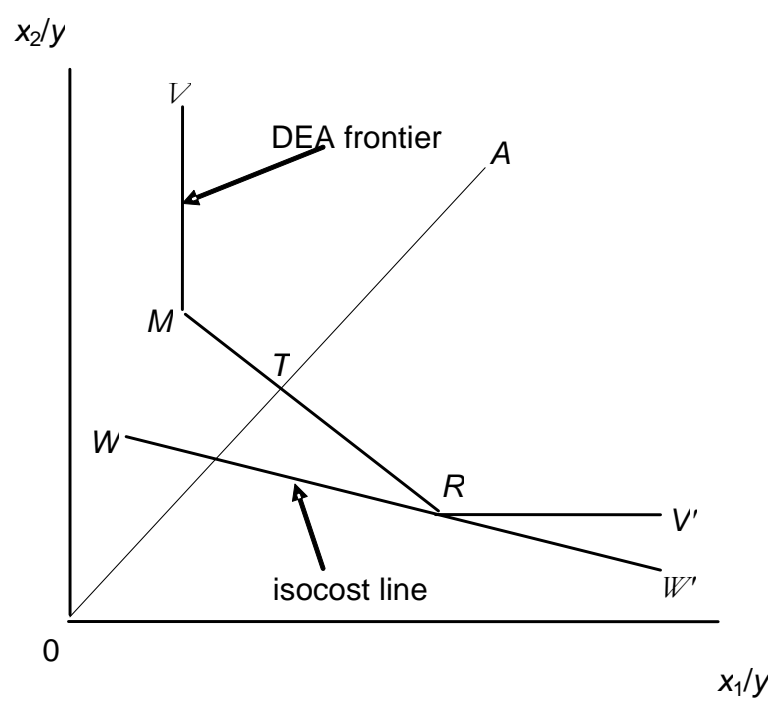

Figure 1: Two-Input Single-Output DEA Frontier

Charnes et al. (1978) developed DEA as a linear programming technique to evaluate the efficiency of public sector non-profit organisations. According to Molyneux et al. (1996), Sherman and Gold (1985) were the first to apply DEA to banking.

The original model proposed by Charnes et al. (1978) and adopted by Sherman and Gold (1985) is formulated as follows:

Objective function

$\max E_{o}=\frac{\sum_{i=1}^{k} u_{i} \psi_{i o}}{\sum_{j=1}^{m} v_{j} x_{j o}}, \quad$ (i.e. maximise $\frac{\text { output index }}{\text { input index }}$ ) 
where:

$\mathrm{o}=$ the branch being assessed from the set of $\mathrm{r}=1,2, \ldots, \mathrm{n}$ bank branches;

$\mathrm{k}=$ the number of outputs at the branches;

$\mathrm{m}=$ the number of inputs at the branches;

$\psi_{\text {ir }}=$ observed output $\mathrm{i}$ at branch $\mathrm{r}$;

$\chi_{\mathrm{jr}}=$ observed input $\mathrm{j}$ at branch $\mathrm{r}$.

\section{Constraints}

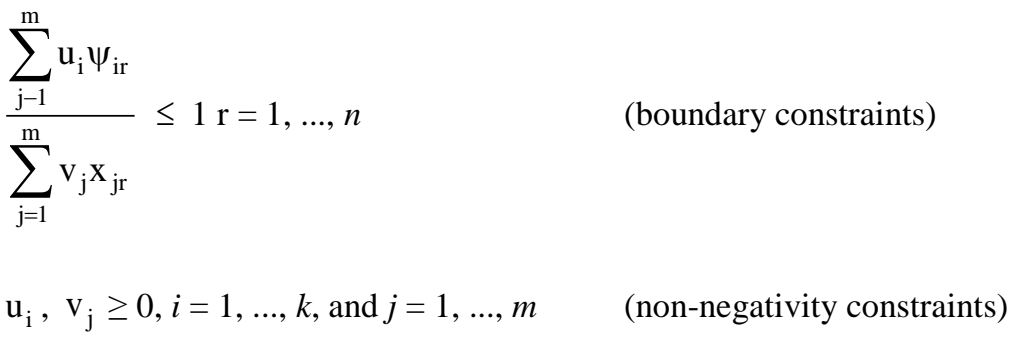

The above analysis is performed repetitively, with each bank branch in the objective function, producing efficiency ratings for each of the $n$ branches. The solution sought is the set of $\left(u_{i}, v_{i}\right)$ values that maximise the efficiency ratio $\mathrm{E}_{\mathrm{o}}$ of the bank branch being rated, without resulting in an output/input ratio 1 when applied to each of the other branches in the data set. (For a more detailed discussion on the DEA methodology, see Avkiran, 1999)

\section{FINANCIAL RATIOS}

According to MacDonald and Koch (2006) if a group of bank presidents are cornered and asked to summarise performance for the past year, most would quote either their bank's return on equity (ROE) or return on assets (ROA). If these measures were higher than those of their peers, they would drop the phrase "highperformance bank" in the conversation. These summarised performance measures are profitability ratios.

Rose and Hudgins (2006) state that the performance of a financial firm refers to how adequately that firm meets the needs of its stockholders, employees, depositors and other creditors, and borrowing customers. At the same time, financial firms must find a way to keep government regulators satisfied that their operating policies, loans and investments are sound, and protecting the public interest.

According to Gardner and Mills (1994) performance analysis entails more than profitability analysis. Ratio analysis also include four other areas (Brigham \& Ehrhardt, 2005), namely liquidity ratios, asset management ratios, e.g. investment policies and loans (advances), debt management ratios, e.g. deposits, purchased funds and capital adequacy, and finally market value ratios. These ratio analysis (except market value ratios) and overall interest rate sensitivity are the decision areas affecting an institution's risk and return and each area helps to explain the bottom line. Performance evaluation is more complicated than simply calculating ratios and common-size statements. The hard part is interpreting the numbers. One calculation, viewed in isolation, means little. It is only informative when compared either with a standard for the industry or industry subgroup or with the firm's recent past performance (Gardner \& Mills, 1994).

Gardner and Mills (1994) state that many researchers have identified the ability of managers to control noninterest expenses while generating target levels of interest and noninterest revenues as a distinguishing characteristic of outstanding performance among depositories. Thus, no "report card" on asset/liability management would be complete without measures of efficiency and productivity. 
In conducting a comprehensive ratio analysis for financial firms, Hempel and Simonson (1999) identify four basic categories of the income statement namely interest income, interest expense, noninterest income and noninterest expense. According to Hempel and Simonson (1999) the first category measures the yield on each type of earning asset. The second category focuses on the interest cost of the bank's various sources of non-equity funds. The third category quantifies noninterest sources of income to examine a bank's performance in earning income from sources other than interest on its earning assets. The final category emphasises control of the components of overhead or noninterest expense, such as salaries and occupancy expenses.

ROE (net income/average total equity) and ROA (net income/average total assets) are the most commonly used ratios of profitability. In order to compare the performance of the four largest banks in South Africa, these two ratios, as is the case with the other ratios, will be calculated for each bank over the eleven years period. According to Rose and Hudgins (2008) net interest margin (NIM) ([interest income - interest expense]/total assets) and net noninterest margin ([noninterest revenues - noninterest expenses]/total assets) are also important ratio measures of profitability. The net interest margin measures how large a spread between interest revenues and interest expenses management has been able to achieve by close control over earning assets and pursuit of the cheapest sources of funding. The net noninterest margin, in contrast, measures the amount of noninterest revenues stemming from service fees the financial firm has been able to collect relative to the amount of noninterest cost incurred (including salaries and wages, repair and maintenance of facilities, and loan loss expenses). MacDonald and Koch (2006) use average earning assets in the calculation of net interest margin and define it as a summary measure of the net interest return on income-producing assets ([net interest income]/average earning assets).

A profitability measure favoured by Gardner and Mills (1994) is the measure, the profit margin (net income/total operating income). It reflects the percentage of each dollar of revenue remaining after all costs and expenses are paid. An institution with a relatively high cost structure has a lower profit margin than a more efficient institution. Hempel and Simonson (1999) use, inter alia, the yield on earning assets as a profitability measure. It is a measure of the gross rate of return on earning assets.

According to MacDonald and Koch (2006) the efficiency ratio has become popular and measures a bank's ability to control noninterest expense relative to net (adjusted) operating income. The efficiency ratio $=$ noninterest expense/(net interest income + noninterest income) and conceptually it indicates how much a bank pays in noninterest expense for one dollar of operating income. (See also Hempel \& Simonson, 1999).

As a measure of efficiency and productivity in depository institutions, Gardner and Mills (1994) use the ratio noninterest income/total operating income to measure the contribution of noninterest income to institutional performance. Another ratio used by them is noninterest income/average total assets. Asset utilisation (AU) is presented by the ratio (total operating income/average total assets) and is used as a productivity measure focused on the firm's ability to generate revenues compared with the asset base on which revenues can be earned.

The financial ratios published by the banks in their annual reports will be used to evaluate the financial and the operating performance of the banks during the sample period.

\section{DATA AND MODEL}

Financial statement data, at year-end from 2001 to 2011, were obtained from the McGregor BFA (2012) database of listed companies' financial statements. The aggregate descriptive statistics (values in thousands of rand, the South African currency) for the four largest South African banks are presented in Table 1.

Table 1: Descriptive Statistics - Aggregate of the Four Largest South African Banks (R,000)

\begin{tabular}{|l|c|c|c|c|}
\hline \multicolumn{1}{|c|}{ Variable } & Mean & Min & Max & Std dev \\
\hline Loans and Investments & $379,444,957$ & $124,099,000$ & $760,387,000$ & $181,425,703$ \\
\hline Noninterest Income & $15,047,007$ & $5,709,000$ & $31,882,000$ & $7,641,514$ \\
\hline Deposits & $465,838,070$ & $141,087,000$ & $1,127,492,000$ & $250,929,665$ \\
\hline Labour Costs & $9,281,348$ & $2,928,000$ & $19,542,000$ & $4,383,264$ \\
\hline Operating Expenditure & $8,362,409$ & $2,481,000$ & $18,093,000$ & $3,943,793$ \\
\hline
\end{tabular}

Source: Compiled from McGregor BFA

Copyright by author(s); CC-BY 
The following model was specified:

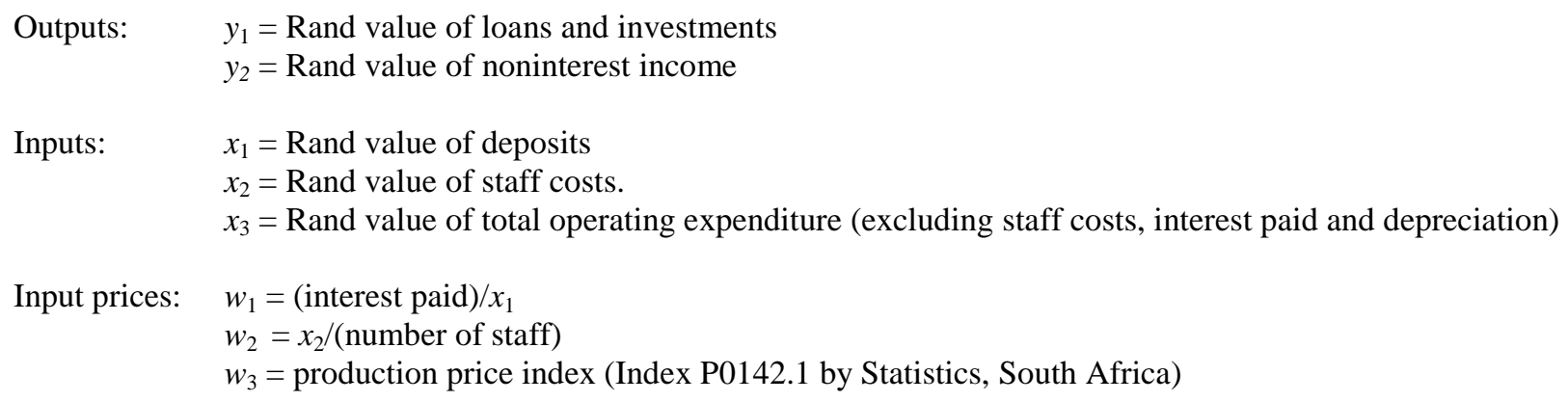

Limited agreement exists in the banking literature on defining outputs, inputs and prices for the inputs. Up to five approaches have been suggested, of which the production approach and the intermediation approach (or variations of it) are the most commonly used ones. According to Berger et al. (1987), under the production approach, banks produce accounts of various sizes by processing deposits and loans, incurring capital and labour costs. Under this approach operating costs are specified in the cost function and number of accounts is used as the output metric, while average account sizes are specified to control for other account characteristics. Under the intermediation approach, banks intermediate deposited and purchased funds into loans and other assets. Under this approach total operating cost plus interest cost are specified and the output is specified in dollars.

According to Resti (1997), a pivotal issue throughout the whole literature based on stock measures of banking products, is the role of deposits. On the one hand, it is argued that they are an input in the production of loans (intermediation or asset approach). Yet, other lines of reasoning (value-added approach, or user cost approach) suggest that deposits themselves are an output, involving the creation of value added, and for which the customers bear an opportunity-cost.

In this paper the intermediation approach is adopted. The main reason for using this approach is because the production approach requires the number of accounts and transactions processed (output measures under the production approach) that were unavailable. Measuring scale and technical efficiency using DEA requires data on output and input quantities, while measuring allocative and cost efficiency also requires data on input prices.

The inputs used in this study are to some extent similar to those used by Sherman and Gold (1985), Rangan et al. (1988), Aly et al. (1990), and Berger et al. (1991). The outputs used correspond to those used by the latter three authors.

\section{DEA RESULTS AND FINANCIAL RATIOS}

The software package DEAP Version 2.1 by Coelli (1996) is purpose-built to solve the DEA problem and has been used in this paper to generate estimates of relative efficiency.

The average efficiency estimates for the banks (all the banks and individual banks) over the sample period, are presented in Table 2 . On average the banks were only 92.5 percent technically efficient (te) during the sample period. This means that the banks were able to improve its outputs by, on average 7.5 percent without any increase in inputs. This indicates that the banks were not able to put their inputs to optimal use. Bank D has the highest average technical efficiency estimate of 97.4 percent, with Bank A the worst performer in technical efficiency (90.4\%). The technical efficiency of three banks was below the average technical efficiency for all the banks. According to Avkiran (1999) technical efficiency investigates how well the production process converts inputs into outputs (i.e. effective implementation of the production plan). 
Table 2: Average Efficiency Estimates over the Sample Period

\begin{tabular}{|l|c|c|c|c|c|}
\hline & & te & ae & ce & Scale \\
\hline \multirow{2}{*}{ All banks } & Mean & 0.925 & 0.960 & 0.888 & 0.879 \\
\cline { 2 - 6 } & Min & 0.416 & 0.793 & 0.407 & 0.406 \\
\hline \multirow{2}{*}{ Bank A } & Mean & 0.904 & 0.908 & 0.822 & 0.807 \\
\cline { 2 - 6 } & Min & 0.834 & 0.793 & 0.689 & 0.643 \\
\hline \multirow{2}{*}{ Bank B } & Mean & 0.915 & 0.977 & 0.894 & 0.906 \\
\cline { 2 - 6 } & Min & 0.416 & 0.901 & 0.407 & 0.406 \\
\hline \multirow{2}{*}{ Bank D } & Mean & 0.906 & 0.988 & 0.894 & 0.882 \\
& Min & 0.784 & 0.928 & 0.783 & 0.777 \\
\cline { 2 - 6 } & Mean & 0.974 & 0.966 & 0.942 & 0.921 \\
\hline
\end{tabular}

Source: Author's calculations

The banks were on average only 96.0 percent allocatively efficient (ae), indicating that the banks were not able to allocate their inputs in the most efficient way. Bank $\mathrm{C}$ has the highest average allocative efficiency with an estimate of 98.8 percent. Bank A, with an average allocative efficiency estimate of 90.8 percent was the worst performing bank. The allocative efficiency of both Bank B and Bank D were higher than the average allocative efficiency for all the banks. According to Avkiran (1999) allocative efficiency is defined as the effective choice of inputs vis-à-vis prices with the objective of minimising production costs (i.e. selection of an effective production plan).

The banks were on average only 88.8 percent cost efficient (ce) during the sample period. Bank D was the most cost efficient bank (94.2\%) during the sample period, while Bank A was the worst performer on cost efficiency (82.2\%). Bank B and Bank C shared second place with a cost efficiency estimate of 89.4 percent, marginally higher that the average for all banks. This is an indication that all four banks can improve their cost efficiency by improved utilisation of its resources and changing the allocation of its inputs. Cost efficiency is the product of allocative efficiency and technical efficiency (ce $=$ ae $x$ te).

The banks were on average only 87.9 percent scale efficient (Scale) during the sample period. Bank D was the bank operating closer to optimum scale efficiency (92.1\%). Bank A was once more the worst performer with a scale efficiency estimate of 80.7 percent. Both Bank B and Bank C reported higher scale efficiency estimates than the average for all the banks. Over the sample period none of these banks were operating at the optimal scale. They were operating at a scale that was either too small or too large.

Certain financial ratios, as reported by the individual banks in their annual reports, are presented in the following tables. The following ratios are presented:

ROE Net income/average total equity

ROA Net income/average total assets

NIM (Interest income - interest expense)/total earning assets

Impairment losses Impairment losses on loans and advances as a percentage of average loans and advances to customers.

NII Noninterest income as percentage of total operating income

Cost Cost to income ratio

The average financial and the average operating performance for the four South African banks are presented in Table 3.

From the results reported in Table 3 it is evident that during 2007 the banks experienced the best average ROE (25.4) and the best average ROA (1.7). The decline in average ROE and average ROA after 2007 may be the result of the Global Financial Crisis (GFC). The lowest average ROE achieved was during 2009 (13.5), while the lowest average ROA (1.0) was achieved during 2002 and 2009. The highest average NIM (3.8) was experienced during 2011 which was the result of the higher demand for credit and the repurchase rate that was kept relatively low. During the previous years of the sample period the average NIM was relatively stable between 3.5 and 3.7. 
Average impairment losses (0.5) reached its lowest point during 2006 with an increase during the following years. As is the case with ROE and ROA, the influence of the GFC is clearly recognisable. In 2011 the average NII (53.0) reached its highest point during the sample period. This is in contradiction to the average NIM that reached its highest point during 2011. It can be expected that a higher NIM will lead to an increase in average interest income which may result in a lower average NII ratio. The lowest average NII ratio (42.1) was achieved during 2009. The lowest average cost to income ratio (50.5) was reached during 2008 with the highest (64.4) during 2002.

Table 3: Average Financial Ratios Reported by the Four South African Banks during the Sample Period 2001 to 2011

\begin{tabular}{|l|c|c|c|c|c|c|c|c|c|c|c|c|}
\hline & $\mathbf{7}$ & $\mathbf{6}$ & $\mathbf{6}$ \\
\hline
\end{tabular}

Source: ABSA, FirstRand Bank, NEDBANK, Standard Bank, various annual reports

The average financial ratios of the individual banks are presented in Table 4.

Table 4: Average Financial Ratios of the Individual Banks over the Sample Period

\begin{tabular}{|c|c|c|c|c|}
\hline & Bank A & Bank B & Bank C & Bank D \\
\hline \multicolumn{5}{|c|}{ Financial Performance } \\
\hline ROE & 20.1 & 22.4 & 13.9 & 21.2 \\
\hline ROA & 1.3 & 1.6 & 0.9 & 1.5 \\
\hline \multicolumn{5}{|c|}{ Operating Performance } \\
\hline NIM & 3.8 & 4.3 & 3.3 & 3.0 \\
\hline Impairment losses & 2.0 & 1.0 & 1.7 & 1.0 \\
\hline NII ratio & 49.1 & 51.3 & 46.6 & 52.1 \\
\hline Cost to income ratio & 55.7 & 55.6 & 62.5 & 53.1 \\
\hline
\end{tabular}

Source: Author's calculations

From the results in Table 4 it is clear that Bank B was the best performer with regard to ROE (22.4), ROA (1.6), NIM (4.3), and impairment losses (1.0 - shared with Bank D). Bank D was the best performer with regard to impairment losses (1.0 - shared with Bank B), NII ratio (52.1), and cost to income ratio (53.1). Bank C was the worst performer with regard to ROE (13.9), ROA (0.9), NII ratio (46.6), and cost to income ratio (62.5). Bank A was the worst performer with regard to impairment losses (2.0) while Bank D was the worst performer with regard to NIM (3.0).

The efficiency estimates reported in Table 2 and the average financial ratio results reported in Table 4 can be used to rank the banks according to their performance. For being the best performer in each of the efficiency estimates and the best performer in the financial ratios, the bank scores four (4) points, followed by three (3) points for second best performer, two points (2) for third best performer and one point (1) for worst performer. This means that the bank with the highest number of points is the best performing bank. The points scored by the individual banks in the efficiency estimates are presented in Table 5.

Table 5: Points Scored According to Average Efficiency Estimates

\begin{tabular}{|l|c|c|c|c|c|}
\hline & te & ae & ce & se & Points Scored \\
\hline Bank A & 1 & 1 & 1 & 1 & 4 \\
\hline Bank B & 3 & 3 & 3 & 3 & 12 \\
\hline Bank C & 2 & 4 & 3 & 2 & 11 \\
\hline Bank D & 4 & 2 & 4 & 4 & 14 \\
\hline
\end{tabular}

Source: Author's calculations 
If the banks are rated according to the results in Table 5 , it is clear that Bank A (4 points) may be regarded as the worst performing bank and Bank D (14 points) as the best performing bank. In the second position is Bank B (12 points) followed by Bank C (11 points) in the third position. Table 6.

The points scored by the individual banks according to their average financial ratios are presented in

Table 6: Points Scored According to Average Financial Ratios

\begin{tabular}{|c|c|c|c|c|}
\hline & Bank A & Bank B & Bank C & Bank D \\
\hline \multicolumn{5}{|c|}{ Financial Performance } \\
\hline ROE & 2 & 4 & 1 & 3 \\
\hline ROA & 2 & 4 & 1 & 3 \\
\hline \multicolumn{5}{|c|}{ Operating Performance } \\
\hline NIM & 3 & 4 & 2 & 1 \\
\hline Impairment losses & 1 & 4 & 2 & 4 \\
\hline NIR ratio & 2 & 3 & 1 & 4 \\
\hline Cost to income ratio & 2 & 3 & 1 & 4 \\
\hline Points scored & 12 & 22 & 8 & 19 \\
\hline
\end{tabular}

Source: Author's calculations

If the banks are rated according to the results in Table 6, it is clear that Bank B (22 points) is the best performing bank according to the average financial ratio results while Bank $\mathrm{C}$ ( 8 points) can be regarded as the worst performing bank. Bank D (19 points) is the second best performer with Bank A (12 points) in the third position.

If the points scored by the banks for the efficiency estimates and the points scored for the average financial ratios are added, Bank A scores 16 points, Bank B 34 points, Bank C 19 points and Bank D 33 points. In this case Bank B can be regarded as the best performing bank and Bank A as the worst performing bank. A summary of the combined points scored by the banks and the rating of the banks are reported in Table 6 .

According to the summary of the points scored and the rating of the banks in Table 7 it is interesting to note how Bank B and Bank D, the best performing banks, changed rating positions, and how Bank A and Bank C, also changed rating positions. (The ratings are indicated in bold in Table 7.) The combined score for Bank B is only marginally higher than the combined score for Bank D. The difference in the combined score for Bank A and the combined score for Bank $\mathrm{C}$ is substantial.

Table 7: Combined Points Scored and Rating of the Four South African Banks

\begin{tabular}{|l|c|c|c|c|}
\hline & Bank A & Bank B & Bank C & Bank D \\
\hline Efficiency Estimates & $4 \mathbf{( 4 )}$ & $12(\mathbf{2})$ & $11(\mathbf{3})$ & $14(\mathbf{1})$ \\
\hline Financial Ratios & $12 \mathbf{( 3 )}$ & $22(\mathbf{1})$ & $8(\mathbf{4})$ & $19(\mathbf{2})$ \\
\hline Combined Results & $16(\mathbf{4})$ & $34(\mathbf{1})$ & $19(\mathbf{3})$ & $33(\mathbf{2})$ \\
\hline
\end{tabular}

Source: Author's calculations

In the case of Bank B, Bank C and Bank D, the difference in points scored according to the efficiency estimates is marginal. The difference in points scored by Bank $\mathrm{A}$ in comparison to the points scored by Bank $\mathrm{C}$ is much larger. Looking at the points scored for the financial ratios, the difference in points scored by the two best performers (Bank B and Bank D) is marginal while the difference in points scored between performer number three (Bank A) and performer number four (Bank C) is more substantial. It is interesting to note that the difference in points scored (the combined results) by the two top performing banks is relatively small compared to the difference in points scored by the other two banks.

\section{CONCLUSIONS}

On average the banks were only 92.5 percent technically efficient during the sample period indicating that the banks were not able to put their inputs to optimal use. Bank D has the highest average technical efficiency 
estimate with Bank A the worst performer in technical efficiency. The technical efficiency of three banks was below the average technical efficiency for all the banks.

The banks were on average only 96.0 percent allocatively efficient indicating that the banks were not able to allocate their inputs in the most efficient way. Bank $\mathrm{C}$ has the highest average allocative efficiency with Bank $\mathrm{A}$, with Bank A the worst performer. The allocative efficiency of both Bank B and Bank D were higher than the average allocative efficiency for all the banks. It is clear that the banks were not able to allocate their inputs in in the most efficient way.

The banks were on average only 88.8 percent cost efficient during the sample period. Bank D was the most cost efficient bank while Bank A was the worst performer. Bank B and Bank C shared second place with a cost efficiency estimate marginally higher that the average for all banks. If the banks could improve the utilisation of their resources and alter the allocation of their inputs, the banks may move closer to being fully cost efficient.

The banks were on average only 87.9 percent scale efficient with Bank D operating the closest to the optimum level. Bank A was once more the worst performer. Both Bank B and Bank C reported higher scale efficiency estimates than the average for all the banks. Over the sample period none of these banks were operating at the optimal scale, which means that they were operating at a scale that was either too small or too large.

During 2007 the banks experienced the best average ROE and ROA. The lowest average ROE achieved was during 2009 while the lowest average ROA was achieved during 2002 and 2009. The highest average NIM was experienced during 2011. Average impairment losses reached its lowest point during 2006. In 2011 the average NII reached its highest point. The lowest average NII ratio was achieved during 2009. The lowest average cost to income ratio was reached during 2008 with the highest during 2002.

Bank B was the best performer with regard to ROE, ROA, NIM and impairment losses. Bank D shares the position with Bank B with regard to impairment losses and was the best performer in both the NII ratio, and cost to income ratio. Bank $\mathrm{C}$ was the worst performer with regard to ROE, ROA, NII ratio, and cost to income ratio. Bank A was the worst performer in the case of impairment losses while Bank D was the worst performer with regard to NIM.

According to the average efficiency estimates Bank A may be rated as the worst performing bank and Bank $\mathrm{D}$ as the best performing bank. In the second position is Bank B followed by Bank $\mathrm{C}$ in the third position. If the financial ratios are used to rate the banks, it is clear that Bank B is the best performing bank and Bank C the worst performing bank. Bank D is the second best performer with Bank $\mathrm{A}$ in the third position. Adding the points scored by the banks for the average efficiency estimates and the points scored for the average financial ratios, Bank B can be rated as the best performing bank and Bank $\mathrm{A}$ as the worst performing bank. In the second position is Bank D with Bank $\mathrm{C}$ in the third position. Depending on whether average efficiency estimates or average financial ratios are used to rate the banks, it is interesting to note how Bank B and Bank D, the best performing banks, changed rating positions, and how Bank $\mathrm{A}$ and Bank $\mathrm{C}$, also changed rating positions.

It appears that there is a positive relationship between bank efficiency and bank profitability, however there is a need to determine the direction of causality - whether the more efficient bank results in the more profitable bank or whether profit is more important than being efficient. The influence of the GFC is also evident in the results presented.

\section{AUTHOR INFORMATION}

Professor Gerhardus van der Westhuizen is a contract employee in the School of Economics and Management Sciences at the Vaal Triangle Campus of the North-West University (South Africa) and holds a D.Com in Economics. He has taught extensively in the Economics programs at North-West University, the Masters Program at the Rand Afrikaans University and University of Johannesburg in the Department of Business Management. His academic research output includes more than 50 peer-reviewed articles and conference presentations. His current research focuses on DEA modeling in the context of bank efficiency and the efficiency of local governments. Email: profgertvdwesthuizen@gmail.com 


\section{REFERENCES}

1. ABSA. (Various years). Annual reports. Retrieved from: http://www.absa.co.za

2. Aly, H. Y., Grabowsky, R., Pasurka, C., \& Rangan, N. (1990). Technical, scale and allocative efficiencies in US banking: An empirical investigation. The Review of Economics and Statistic, May, 211-218.

3. Avkiran, N. K. (1999). An application reference for data envelopment analysis in branch banking: Helping the novice researcher. International Journal of Bank Marketing, 17(5), 206-220.

4. Berger, A. N., Hanweck, G. A., \& Humphrey, D. B. (1987). Competitive viability in banking: Scale, scope and product mix economies. Journal of Monetary Economics, 20, 501-520.

5. Berger, A. N., \& Humphrey, D. B. (1991). The dominance of inefficiencies over scale and product mix economies in banking. Journal of Monetary Economics, 28, 117-148.

6. Berger, A. N., \& Humphrey, D. B. (1997). Efficiency of financial institutions: international survey and directions for further research. European Journal of Operational Research, 98, 175-212.

7. $\quad$ Bessis, J. (2002). Risk management in banking. New York: Wiley.

8. Brigham, E. F., \& Ehrhardt, M. C. (2005). Financial management: Theory and practice. Mason: Thomson/South-Western.

9. Chang, T.-P., Hu, J.-L., Chou, R. Y., \& Sun, L. (2012). The sources of bank productivity growth in China during 2002-2009: A disaggregation view. Journal of Banking and Finance. Retrieved from http://dx.doi.org/10.1016/j.jbankfin.2012.03.003.

10. Charnes, A., Cooper, W. W., \& Rhodes, E. (1978). Measuring efficiency of decision-making units. European Journal of Operations Research, 2, 429-444.

11. Coelli, T. (1996). A guide to DEAP version 2.1, A data envelopment analysis (computer) program. CEPA Working Paper 96/07, Department of Econometrics, University of New England, Armidale.

12. Department of Bank Supervision. (Various years). DI 200 reports and BA 120 reports. Retrieved from http://www.resbank.co.za/sarbdata/ifdata/periods.asp?type=DI200

13. Devaney, M., \& Weber, W. L. (2000). Productivity growth, market structure, and technological change: Evidence from the rural banking sector. Applied Financial Economics, 10, 587-595.

14. Drake, L. (2001). Efficiency and productivity change in UK banking. Applied Financial Economics, 11, 557-571.

15. FirstRand Bank. (Various years). Annual reports. Retrieved from http://www.firstrand.co.za

16. Gardner, M. J., \& Mills, D.L. (1994). Managing financial institutions: An asset liability approach. Orlando: The Dryden Press.

17. Halkos G. E., \& Salamouris D. S. (2004). Efficiency measurement of the Greek commercial banks with the use of financial ratios: A data envelopment analysis approach. Management Accounting Research, 15, 201224.

18. Hempel, G. H., \& Simonson, D. G. (1999). Bank management. Text and cases. New York: Wiley.

19. Luo, X. (2003). Evaluating the profitability and marketability efficiency of large banks: An application of data envelopment analysis. Journal of Business research, 56. 627-635.

20. MacDonald, S. S., \& Koch, T. W. (2006). Management of banking. Mason: Thomson.

21. Matthews, K., \& Zhang, N. (2010). Bank productivity in China, 1997-2007: Measurement and convergence. China Economic Review, 21, 617-628.

22. McGregor. (2012). BFA database. Retrieved from: www.mcgregorbfa.com/pages/researchdomain.aspx

23. Mendes, V., \& Rebelo, J. (1999). Productive Efficiency, technological change and Productivity in Portuguese Banking. Applied Financial Economics, 9(5), 513-521.

24. Molyneux, P., Altunbas, Y., \& Gardener, E. (1996). Efficiency in European banking. Wiley: Chichester.

25. NEDBANK. (Various years). Annual report. Retrieved from http://www.nedbankgroup.co.za

26. Oberholzer, M., \& Van der Westhuizen, G. (2004). An empirical study on measuring profitability and efficiency of bank regions. Meditari (Accounting Research), 12, 165-178.

27. O'Donnell, C. J., \& van der Westhuizen, G. (2002). Regional comparisons of banking performance in South Africa. The South African Journal of Economics, 70(3), 485-518.

28. Okeahalam, C. C. (2006). Production efficiency in the South African banking sector: A stochastic analysis. International Review of Applied Economics, 20(1), 103-123.

29. Oral, M., \& Yolalan, R. (1990). An empirical study on measuring operating efficiency and profitability of bank branches. European Journal of Operational Research, 46, 282-294. 
30. Rangan, N., Grabowsky, R., Aly, H.Y., \& Pasurka, C. (1988). The technical efficiency of US banks. Economics letters, 28, 169-175.

31. Resti, A. (1997). Evaluating the cost-efficiency of the Italian banking system: What can be learned from joint application of parametric and non-parametric techniques. Journal of Banking and Finance, 21, 221250.

32. Rose, P. S., \& Hudgins, S.C. (2005). Bank management and financial services. McGraw Hill: Boston.

33. Seiford, L. M., \& Zhu, J. (1999). Profitability and marketability of the top 55 U.S. commercial banks. Management Science, 45(9), 1270-1288.

34. Sherman, H. D., \& Gold, F. (1985). Bank branch operating efficiency. Evaluation with data envelopment analysis. Journal of Banking and Finance, 9, 297-315.

35. Sherman, H. D., \& Ladino, G. (1995). Managing bank productivity using data envelopment analysis (DEA). Interfaces, 25, 60-73.

36. Standard Bank. (Various years). Annual reports. Retrieved from http://www.standardbank.co.za

37. Van der Westhuizen, G., \& Oberholzer, M. (2003). A model to compare bank size and the performance of banks by using financial statement analysis and data envelopment analysis. Management Dynamics: Contemporary Research, 12(4), 18-26.

38. Van der Westhuizen, G. (2008). Estimating technical and scale efficiency and sources of efficiency change in banks using balance sheet data: A South African study. Journal for Studies in Economics and Econometrics, 32(1), 23-45.

39. Van der Westhuizen, G., \& Oberholzer, M. (2009). The role of interest income and noninterest income on the performance of four large South African banks, Studia Universitatis Babes Bolyai Oeconomica, 54(2), $100-114$.

40. Van der Westhuizen, G. (2010). The role of interest income and non-interest income on the relative efficiency of bank regions: The case of a large South African bank, Studia Universitatis Babes Bolyai Oeconomica, 55(2), 3-23.

41. Van der Westhuizen, G. (2012). Change in the composition of bank income and its effect on the changes in the efficiency of bank regions. International Business and Economics Research Journal, 11(6), 631-646.

42. Vassiloglou, M., \& Giokas, D. (1990). A study of the relative efficiency of bank branches: An application of data envelopment analysis. Journal of the Operational Research Society, 41(7), 591-597.

43. Yeh, Q. (1996). The application of data envelopment analysis in conjunction with financial ratios for bank performance evaluation. Journal of the Operational Research Society, 47, 980-988. 